\title{
Relationship between urinary and serum growth hormone and pubertal status
}

\author{
E C Crowne, W H B Wallace, S M Shalet, G M Addison, D A Price
}

\begin{abstract}
Urinary growth hormone (uGH) excretion and serum growth hormone concentrations have been compared in three groups of children. Group 1 consisted of 21 children who had had cranial irradiation as part of their treatment for acute lymphoblastic leukaemia; group 2, 18 normal children; and group 3,12 boys with constitutional delay in growth and puberty who were in early puberty. Children in groups 1 and 2 each had a 24 hour serum growth hormone profile (sampling every 20 minutes) and concurrent urine collection. The 12 boys in group 3 had a total of 21 profiles (sampling every 15 minutes for 12 hours) and concurrent urine collections.

In the prepubertal children $(n=17)$, in both groups 1 and 2 , there was a significant correlation between mean serum growth hormone and total uGHng/g creatinine. There were also significant correlations between total $\mathbf{u G H n g / g}$ creatinine and both peak serum growth hormone and mean amplitude of the pulses in the growth hormone profile. In the pubertal children $(n=22)$, in groups 1 and 2, whether combined or in separate groups, there was no significant correlation between total $\mathbf{u G H n g / g}$ creatinine and mean serum growth hormone, peak serum growth hormone, or mean amplitude of the pulses in the growth hormone profile. In group 3 there were significant correlations between total uGHng/g creatinine and both the mean serum growth hormone and mean amplitude of the pulses in the profile. Therefore uGH estimations appear to correlate well with serum growth hormone profiles in children who are prepubertal or in early puberty, but not in those further advanced in pubertal development. These results may reflect a variation in the renal handling of growth hormone during pubertal development. uGH estimation may be an unreliable screening investigation for growth hormone insufficiency in mid to late puberty.
\end{abstract}

The diversity of tests of growth hormone secretion in clinical use indicates the absence of an ideal test of growth hormone secretion. In clinical practice pharmacological stimulation tests such as insulin, arginine, or glucagon with an arbitrarily assigned 'normal' cut off value have been used to identify growth hormone deficient children. These tests do not provide information about physiological growth hormone secretion, and 24 hour serum growth hormone profiles for the assessment of physiological growth hormone secretion have obvious drawbacks in terms of invasiveness and cost. Hence the interest in estimation of urinary excretion of growth hormone as a non-invasive, easily performed test. Growth hormone assays have now attained the sensitivity required to detect the minute amounts of the hormone excreted in the urine, ${ }^{1-3}$ and their use is being advocated as a means of screening for growth hormone deficiency. ${ }^{4}$

Abnormalities in growth hormone secretion in children and adults who have had cranial irradiation as part of their treatment for malignancies are well established. ${ }^{5-8}$ Abnormalities ranged from growth hormone deficiency defined by classical criteria, ${ }^{9}$ neurosecretory dysfunction with normal growth hormone responses to pharmacological tests but subnormal physiological growth hormone secretion, ${ }^{7}$ and a failure of the puberty associated rise in spontaneous growth hormone secretion. ${ }^{8}$ Children who have had cranial irradiation are therefore a particular group in whom screening tests of growth hormone need to be reliable enough to detect subtle changes in physiological growth hormone secretion.

Other categories of children frequently seen in a paediatric growth clinic include those with constitutional delay in growth and puberty (CDGP) or familial short stature. A simple, easily performed non-invasive means of assessing growth hormone secretion in such individuals would be very helpful.

In this study we have therefore compared urinary growth hormone (uGH) estimations and serum growth hormone profiles in three groups of children: normal children, children who have had low dose cranial irradiation as part of their treatment for acute lymphoblastic leukaemia (ALL), and boys with CDGP.

Patients and methods

GROUP 1: AFTER CRANIAL IRRADIATION

Twenty one children, aged 6.9-18.2 years (nine girls, 12 boys) who had received prophylactic cranial irradiation during treatment for ALL were studied. Nineteen received $18 \mathrm{~Gy}$ in 10 fractions over 14 days and two received 24 Gy in 10 fractions over 14 days. All 21 had received chemotherapy according to standard UK protocols, were in first remission, and a mean (SD) $6.4(1 \cdot 9)$ years from radiotherapy.

GROUP 2: NORMAL CHILDREN

Eighteen normal children, aged $3 \cdot 8-18 \cdot 9$ years (six girls, 12 boys) were studied. Ten were 
normal siblings of group 1 and eight were children under investigation for genetic short stature (height velocity normal and normal growth hormone response to pharmacological stimulation tests but with a mid-parental height less than the 10th centile and a standing height more than $2 \mathrm{SD}$ below the mean).

GROUP 3: CDGP

Twelve boys under investigation for CDGP were studied. They had a total of 21 profiles with concurrent urine collections before and after treatment with either low dose testosterone, oxandrolone, or placebo. Only six of the profiles were performed while the boys were actively receiving either oxandrolone $(n=2)$ or testosterone $(n=4)$.

The groups were further subdivided by pubertal stage according to the method of Tanner and Whitehouse. ${ }^{10}$ Children in groups 1 and 2 each had a 24 hour growth hormone profile sampling every 20 minutes with concurrent urine collection (0900-0900 hours). Group 3 boys had an overnight 12 hour profile on each occasion (2000-0800 hours), with sampling every 15 minutes and a concurrent urine collection. Details of the children at the time of the profile are shown in table 1 .

All the studies were approved by the local ethical committee and informed consent was obtained from the children and their parents.

\section{ASSAYS}

Serum growth hormone profiles were assayed in one batch using a standard diagnostic immunoradiometric assay (IRMA) kit (Netria, St Bartholomew's Hospital, London), and international reference standards. Urine samples were collected in polythene bottles kept at $4^{\circ} \mathrm{C}$ during the collection. Urine volumes were then measured and aliquots stored at $-40^{\circ} \mathrm{C}$ in $0 \cdot 1 \%$ bovine serum albumin and $0 \cdot 1 \%$ azide solution until assayed, when aliquots were first dialysed against a phosphate buffer for 24 hours at $4^{\circ} \mathrm{C}$. Growth hormone concentration was measured by a two step IRMA using $1.5 \mathrm{ml}$ of dialysed urine. The first step consisted of a 24 hour incubation with $100 \mu \mathrm{l}$ of ${ }^{125}$ I labelled mouse monoclonal antihuman growth hormone antibody, and the second a 24 hour incubation with $100 \mu \mathrm{l}$ of sheep polyclonal antigrowth hormone

Table 1 Age and pubertal stage at the time of profile. Results are mean (SD)

\begin{tabular}{|c|c|c|c|c|}
\hline Group & $\begin{array}{l}\text { Age at } \\
\text { study }\end{array}$ & $\begin{array}{l}\text { Pubertal } \\
\text { stage }\end{array}$ & $\begin{array}{l}\text { Time since } \\
\text { treatment }\end{array}$ & $\begin{array}{l}\text { Age at } \\
\text { treatment }\end{array}$ \\
\hline \multicolumn{5}{|c|}{ 1: ALL (after irradiation) } \\
\hline $\begin{array}{l}\text { Prepubertal } \\
(\mathbf{n}=7)\end{array}$ & $9 \cdot 6(1 \cdot 8)$ & - & $6 \cdot 6(1 \cdot 8)$ & $3 \cdot 8(2 \cdot 1)$ \\
\hline$(n=14)$ & $14 \cdot 1(2 \cdot 0)$ & $\begin{array}{l}\text { TV 5-12 } \mathrm{ml}(\mathrm{n}=3), \text { TV } 25 \mathrm{ml} \\
(\mathrm{n}=3) ; \mathrm{B} 3-\mathrm{B} 4(\mathrm{n}=2), \text { B5 }(\mathrm{n}=6)\end{array}$ & $6.5(1.7)$ & $7 \cdot 3(3 \cdot 1)$ \\
\hline \multicolumn{5}{|c|}{ 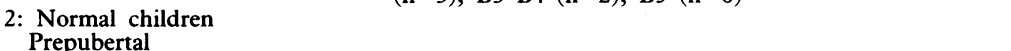 } \\
\hline $\begin{array}{l}(n=10) \\
\text { Pubertal }\end{array}$ & $8 \cdot 7(2 \cdot 4)$ & - & - & - \\
\hline$(n=8)$ & $15 \cdot 3(2 \cdot 6)$ & $\begin{array}{l}\text { TV 5-12 } \mathrm{ml}(\mathrm{n}=3), \text { TV } 25 \mathrm{ml} \\
(\mathrm{n}=3) ; \mathrm{B} 3 \quad(\mathrm{n}=1), \text { B5 }(\mathrm{n}=1)\end{array}$ & - & - \\
\hline 3: CDGP & $14 \cdot 5(0 \cdot 9)$ & $\begin{array}{l}\text { TV 4-6 } \mathrm{ml} \quad(\mathrm{n}=14), \\
\text { TV } 8-12 \mathrm{ml}(\mathrm{n}=7)\end{array}$ & & \\
\hline
\end{tabular}

$\mathrm{TV}=$ testicular volume, $\mathrm{B}=$ breast stage. antibody coupled to a solid phase (antibodies obtained from Netria). Both incubations were at $4^{\circ} \mathrm{C}$. Sensitivity was $0.8 \mathrm{pg} / \mathrm{ml}$, intra-assay coefficients of variation were $2 \cdot 0-8 \cdot 1 \%$, and interassay coefficients of variation $6 \cdot 6-8 \cdot 4 \%{ }^{11}$

Urinary creatinine estimations were performed by the standard Jaffé kinetic method.

\section{CALCULATIONS AND STATISTICS}

Results are expressed as mean (SD). Results of $\mathrm{uGH}(22 \mathrm{pg} / \mathrm{ml}=1 \mu \mathrm{mol} / \mathrm{l})$ are expressed as $\mathrm{ng}$ per gram of creatinine to avoid inaccuracies due to incomplete or inaccurate urine collections and to allow comparison with published reports. Growth hormone profiles were analysed using the Pulsar Peak Detection Programme. ${ }^{12}$ Correlations and regressions were calculated by standard least squares. Differences between groups were analysed using the Mann-Whitney $\mathrm{U}$ test. The significance of regression lines was calculated using Student's unpaired $t$ test, the significance of the difference between regression lines calculated using a method of weighting. ${ }^{13}$

\section{Results}

There were no significant differences in mean peak and total concentrations of serum growth hormone within group 2, that is between the normal siblings and those under investigation for genetic short stature. In group 1, there was no significant difference in time since cranial irradiation between the prepubertal and pubertal children $(6.6(1.8) v 6.5(1.7)$ years) but there was a significant difference in age at cranial irradiation between the prepubertal and puberta children $(3.8(2 \cdot 1) v 7 \cdot 5(3 \cdot 0)$ years, $\mathrm{p}<0.05)$.

\section{RELATIONSHIP BETWEEN SERUM GROWTH} HORMONE PROFILES AND UGH EXCRETION IN PREPUBERTAL CHILDREN (FIG 1)

There was a significant correlation between mean serum growth hormone and total $\mathrm{uGHng} / \mathrm{g}$

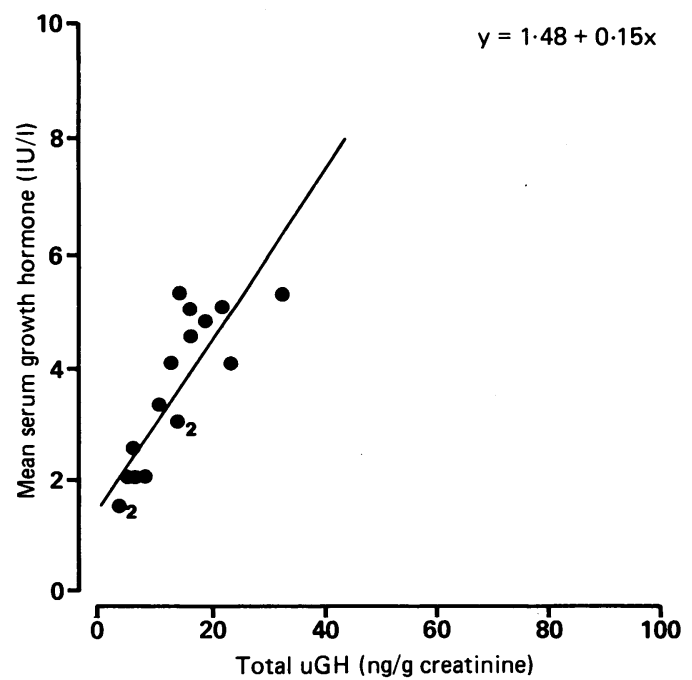

Figure 1 Relationship between total $u G H$ excretion and mean serum growth hormone concentrations in 17 prepubertal mean serum growth hormone concentrations in 17 prepuber
children. Conversion factor for growth hormone: $2 I U / l=$ children. 
creatinine in the prepubertal children $(\mathrm{r}=0.82$; $\mathrm{p}<0.001$ ). The relationship was described by the regression equation $y=1 \cdot 48+0 \cdot 15 x$ (fig 1 ). The correlation between these two parameters was also significant in groups 1 and 2 taken separately $(r=0.88, p=0.009 ; r=0.84, p=0.003$ respectively), and there was no significant difference in the regression equations between the two groups. There were also significant correlations in the prepubertal children between total uGHng/g creatinine and both peak growth hormone in the growth hormone profile $(r=0.86, p<0.001)$ and mean pulse amplitude in the growth hormone profile $(r=0.71$, $\mathrm{p}=0.002$ ).

\section{RELATIONSHIP BETWEEN SERUM GROWTH} HORMONE PROFILE AND UGH EXCRETION IN BOYS WITH CDGP IN EARLY PUBERTY

There were significant correlations between total $\mathrm{uGHng} / \mathrm{g}$ creatinine and both mean serum growth hormone $(r=0.74, p<0.001)$ and mean amplitude of the growth hormone pulses in the 12 hour profile $(r=0.4, p=0.05)$ in these boys. There was, however, no significant correlation between the total uGH excreted and the peak growth hormone in the profile $(r=0 \cdot 4, p=0 \cdot 12)$.

\section{RELATIONSHIP BETWEEN SERUM GROWTH HORMONE PROFILES AND UGH EXCRETION IN PUBERTAL CHILDREN (FIG 2)}

The relationship between mean serum growth hormone and total $\mathrm{uGHng} / \mathrm{g}$ creatinine was not significant in the pubertal children $(r=-0 \cdot 26$, $p=0.24$ ) as seen in fig 2 . The regression equation $(y=4.84-0.03 x)$ was significantly different to that of the prepubertal group $(\mathrm{p}<0.001)$ but not significantly different from zero. The correlation between these two parameters was also not significant in either group 1 or 2 taken separately $(r=-0.02, p=1.0$; $\mathrm{r}=-0 \cdot 4, \mathrm{p}=0 \cdot 22$ respectively). Nor was there a significant correlation between these parameters in the boys and girls taken separately $(r=0 \cdot 2$, $\mathrm{p}=0.60 ; \mathrm{r}=-0.6, \mathrm{p}=0.1$ respectively). In addition, there were no significant correlations

Table 2 Factors affecting renal function in the 21 children treated for $A L L$

\begin{tabular}{|c|c|c|c|}
\hline $\begin{array}{l}\text { Patient } \\
\text { No }\end{array}$ & $\begin{array}{l}\text { Intravenous pyelogram } \\
\text { at diagnosis }\end{array}$ & Nephrotoxic drugs & Renal function \\
\hline $\begin{array}{r}1 \\
2 \\
4 \\
6 \\
7 \\
12 \\
16 \\
\\
3 \\
5 \\
8 \\
9 \\
10 \\
11 \\
13 \\
14 \\
15 \\
17 \\
18 \\
19 \\
20 \\
21\end{array}$ & $\begin{array}{l}\text { Normal } \\
\text { Normal } \\
\text { Normal } \\
\text { Normal } \\
\text { Normal } \\
\text { Normal } \\
\text { Normal } \\
\text { Normal } \\
\text { Normal } \\
\text { Normal } \\
\text { Normal } \\
\text { Not performed } \\
\text { Normal } \\
\text { Normal } \\
\text { Normal } \\
\text { Leukaemic infiltration } \\
\text { Normal } \\
\text { Normal } \\
\text { Normal } \\
\text { Leukaemic infiltration } \\
\text { Normal }\end{array}$ & $\begin{array}{l}\text { ertal } \\
\text { Amikacin } \\
\text { Amikacin } \\
\overline{\text { Gentamicin }} \\
\text { Amikacin } \\
\overline{\text { Netilmicin }} \\
\text { rtal } \\
\text { Gentamicin, amikacin } \\
\text { Amikacin } \\
\overline{\text { Amikacin }} \\
\text { Amikacin } \\
\text { Gentamicin, and amikacin } \\
\overline{\text { Netilmicin, amikacin }} \\
\text { Gentamicin } \\
\text { Amikacin } \\
\overline{-} \\
\overline{\text { Netilmicin }}\end{array}$ & $\begin{array}{l}\mathbf{N} \\
\mathbf{T} \\
\mathbf{N} \\
\mathbf{T} \\
\mathbf{N} \\
\mathbf{N} \\
\mathbf{T} \\
\mathrm{T} \\
\mathbf{N} \\
\mathbf{N} \\
\mathbf{N} \\
\mathbf{T} \\
\mathbf{T} \\
\mathbf{N} \\
\mathbf{T} \\
\mathbf{N} \\
\mathbf{N} \\
\mathbf{N} \\
\mathbf{N} \\
\mathbf{T} \\
\mathbf{N}\end{array}$ \\
\hline
\end{tabular}

* Renal function: $\mathrm{N}=$ normal blood urea and creatinine concentration, $\mathrm{T}=$ transiently raised concen trations during treatment, subsequently normal.

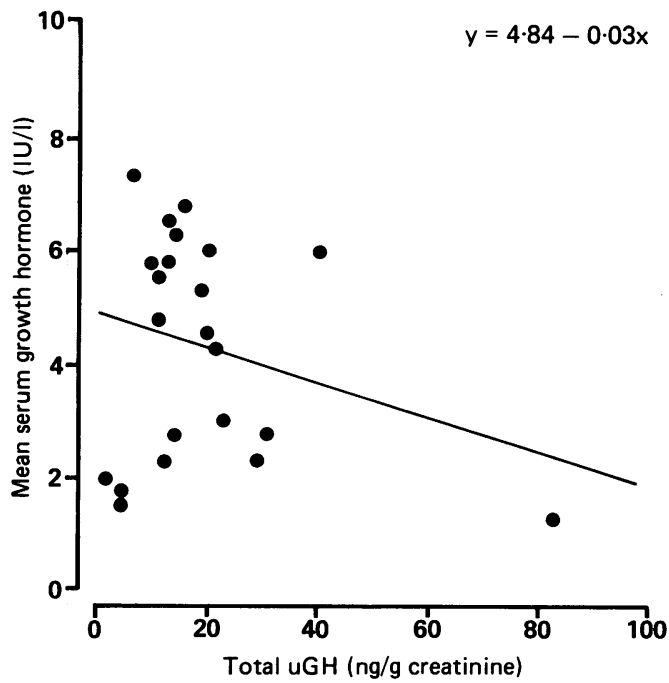

Figure 2 Relationship between total $u G H$ excretion and mean serum growth hormone concentrations in 22 pubertal children. Conversion factor for growth hormone: $2 I U / l=$ $1 \mu g / l$.

in the pubertal group between total $\mathrm{uGHng} / \mathrm{g}$ creatinine and either peak growth hormone in the growth hormone profile $(r=-0.29$, $p=0.2$ ) or mean amplitude of the growth hormone pulses in the growth hormone profile $(\mathrm{r}=-0 \cdot 34, \mathrm{p}=0 \cdot 2)$. Expressing $\mathrm{uGH}$ excretion as a $\mathrm{uGH} / \mathrm{g}$ creatinine ratio or as total $\mathbf{u G H}(\mathrm{pg})$ did not alter these results. The six pubertal boys in groups 1 and 2 with testicular volumes less than $12 \mathrm{ml}$ (that is, at a similar pubertal stage to the boys in group 3) did, however, show a significant correlation between total $\mathrm{uGHng} / \mathrm{g}$ creatinine and both mean serum growth hormone and mean amplitude of the growth hormone pulses $(r=0.74, p=0.09 ; r=0.72$, $p=0.01$ respectively) when analysed separately.

\section{RENAL FUNCTION}

All the children studied had normal plasma urea and creatinine concentrations. In particular the group with ALL had normal renal function after their chemotherapy. Factors during the course of their treatment affecting renal function are shown in table 2 .

All the children except one had an intravenous pyelogram at diagnosis. Two showed evidence of leukaemic infiltration. The children all received chemotherapy according to standard protocols and these did not include known nephrotoxic drugs. During their treatment, however, 14 children received antibiotics known to be nephrotoxic for treatment of intercurrent infections while immunosuppressed. Five were in the prepubertal group and nine in the pubertal group. All have subsequently had normal renal function tests, although during treatment eight children had plasma urea and creatinine concentrations transiently raised above age related normal values; three were from the prepubertal group and five from the pubertal group.

Discussion

Growth hormone excreted into the urine represents less than $0.002 \%$ of serum concen- 
trations, ${ }^{14}$ and is the end product of renal metabolism including glomerular filtration, followed by extensive tubular reabsorption, and lysosomal hydrolysis. The rate limiting step under normal conditions is the filtration process as neither tubular reabsorption nor intracellular hydrolysis is saturated. ${ }^{15}$ Endogenous growth hormone production has been shown to increase in puberty by an amplitude modulated process. ${ }^{16}$ Furthermore, renal excretion of $\mathbf{u G H}$ increases in spontaneous puberty ${ }^{14}{ }^{17}$ and after the treatment of delayed puberty with testosterone. ${ }^{14}$ Glomerular filtration rate, however, also increases in puberty, although changes in tubular function have not been described. Therefore our results showing a loss of the relationship between serum growth hormone and uGH during puberty are not totally unexpected in view of the changes in a number of important variables. The fact that our boys with CDGP showed a significant correlation between $\mathrm{uGH}$ excretion and serum growth hormone concentrations is interesting but not contradictory. Growth hormone concentrations in early puberty do not differ significantly from those in prepubertal boys ${ }^{16}$ and the majority of this group were in early puberty. Unfortunately the mean values shown in table 3 are not directly comparable as groups 1 and 2 had 24 hour profiles and urine collections in group 3 boys had 12 hour studies. The mean total concentrations in group 3 are likely to be higher than those of groups 1 and 2 as they do not include daytime growth hormone secretion when less growth hormone is produced.

Significant correlations between uGH excretion and both the growth hormone response to provocative tests ${ }^{18} 19$ and the mean serum growth hormone concentrations during profiles in diabetic and normal children, ${ }^{17}$ normal, short statured and growth hormone deficient children, ${ }^{20}$ and normal and short statured adults $^{21}$ have been described. Okuna et al investigated prepubertal children only, ${ }^{20}$ and Weissberger et al studied adults, patients with acromegaly, and only 12 short children, whose pubertal stage was not specified. ${ }^{21}$ Edge et al analysed changes in $\mathrm{uGH}$ excretion during puberty but did not state the pubertal status of the children undergoing growth hormone profiles. ${ }^{17}$ Therefore the significant correlation found in the latter group may reflect a majority of prepubertal and early pubertal children (age range $5 \cdot 9-15 \cdot 9$ years $).{ }^{17}$

Table 3 Relationship between mean serum growth hormone and total uGHng/g creatinine. Results are mean $(S D)$

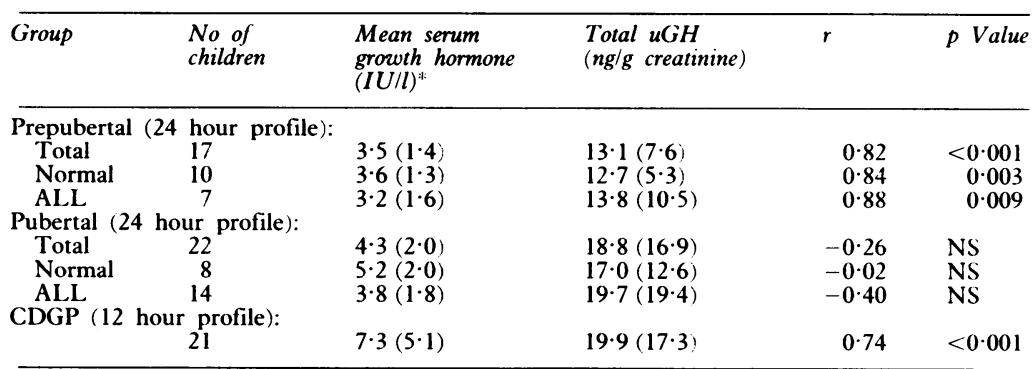

"Conversion factor for growth hormone: $2 \mathrm{IU} / \mathrm{l}=1 \mu \mathrm{g} / \mathrm{l}$.
In adults single overnight uGH measurements were found not to discriminate completely between those with acromegaly and normal controls, ${ }^{22}$ nor was there a significant correlation between uGH excretion and serum growth hormone concentrations in the adults with active acromegaly. ${ }^{21}$ This may be due to changes in renal function caused by growth hormone itself. $^{23}$ In addition, within an individual, significant day to day variability in $\mathrm{uGH}$ excretion of the order of $30 \%$ has been described. ${ }^{24}$ The latter is most probably due to changes in renal function. The lack of any correlation between the dose of growth hormone injected and amount of $\mathrm{uGH}$ measured in the urine in growth hormone insufficient children ${ }^{14}$ provides further evidence for the individual variability of growth hormone handling. Furthermore, the excretion of $\mathrm{uGH}$ increases in renal failure and diabetic children regardless of changes in growth hormone secretion, ${ }^{17} 25$ but it is not significantly correlated with the excretion of other urinary proteins ${ }^{26}$ thereby underlining the importance of variations of renal function on $\mathrm{uGH}$ excretion.

Group 1 (ALL) would have been at particular risk of incurring renal damage either as a result of their original disease or in the course of its treatment. Although there is no evidence of overt renal problems in the ALL children studied, they could have incurred sufficient tubular damage during treatment to affect renal handling of growth hormone. The fact that the prepubertal children with ALL were not significantly different from the normal prepubertal children in their excretion of $\mathrm{uGH}$, however, argues against significant tubular damage affecting $\mathrm{uGH}$ excretion in these children. There was no difference in treatment, clinical course, or time elapsed since treatment between the prepubertal and pubertal irradiated children, although the children who were pubertal at the time of study were significantly older when originally treated than the prepubertal children $(7 \cdot 3(3 \cdot 1) v 3 \cdot 8(2 \cdot 1)$ years, $\mathrm{p}<0 \cdot 05)$. If anything this should render them less vulnerable, as young children are more susceptible to permanent kidney damage from insults such as urinary tract infections. These observations counter the suggestion that tubular damage in group 1 disrupted uGH excretion. Furthermore the absence of a relationship between $\mathrm{uGH}$ excretion and serum concentrations in the normal pubertal group cannot be explained by renal pathology.

In conclusion, further investigation of the impact of both physiological and pathological changes in renal function on $\mathrm{uGH}$ excretion are necessary to determine the reliability of $\mathrm{uGH}$ as a screening test for growth hormone deficiency. Estimation of uGH does not appear to reflect serum growth hormone concentrations reliably in mid to late puberty and thus is not an appropriate screening test for growth hormone deficiency during puberty. Careful measurement of growth and the more traditional methods of growth hormone assessment remain essential.

We are grateful for the support of the Leukaemia Research Fund and Eli Lilly during this study and to Mr D Ryder for statistical advice. 
1 Girard J, Erb T, Pampalone A, et al. Growth hormone in urine: development of an ultrasensitive assay applicable to plasma and urine. Horm Res 1987;28:71-80.

2 Hourd P, Edwards R. Measurement of human growth hormone in urine: development and validation of a sensitive and specific assay. $\mathcal{F}$ Endocrinol 1989;121:167-75.

3 Hashida S, Ishikawa E, Kato $\mathrm{Y}$, et al. Human growth hormone (hGH) in urine and its correlation to serum hGH hormone (hGH) in urine and its correlation to serum hGH assay. Clin Chim Acta 1987;162:229-35.

4 Walker JM, Wood PJ, Williamson S, Betts PR, Evans AJ. Urinary growth hormone excretion as a screening test for growth hormone deficiency. Arch Dis Child 1990;65:89-92.

5 Shalet SM. Endocrine consequences of treatment of malignant disease. Arch Dis Child 1989;64:1635-41.

6 Rappaport R, Brauner R. Growth and endocrine disorders secondary to cranial irradiation. Pediatr Res 1989;25:561-7.

7 Blatt J, Bercu BB, Gillin JC, Mendelson WB, Poplack DG Reduced pulsatile growth hormone secretion in children
after therapy for acute lymphoblastic leukemia. 7 Pediatr after therapy for

8 Moell C, Garwicz S, Westgren U, Wiebe T. AlbertssonWikland K. Suppressed spontaneous secretion of growth hormone in girls after treatment for acute lymphoblastic leukaemia. Arch Dis Child 1989;64:252-8.

9 Parkin JM. The short child. In: Brook CGD, ed. Clinical paediatric endocrinology. 2nd Ed. Oxford: Blackwell, 1989: 96-117.

10 Tanner J, Whitehouse RH. Clinical longitudinal standards for height, weight, height velocity, weight velocity and stages in puberty. Arch Dis Child 1976;51:170-9.

11 Price DA, Addison GM, Herbert ED. Increase in urinary growth hormone in puberty. Arch Dis Child 1990;65: growth

12 Merriam GR, Wachter KW. Algorithms for the study of episodic hormone secretion. Am $\mathcal{f}$ Physiol 1982;243. E310-8

13 Armitage P, Berry G. Statistical methods in medical research. 2nd Ed. Oxford: Blackwell, 1987:275.

14 Girard J, Fischer-Wasels T. Measurement of urinary growth hormone. Horm Res 1990;33(suppl 4):12-8.

15 Maack T, Park CH, Camargo MF. In: Seldin DW, Griebisch G, eds. The kidney: physiology and pathophysiology. New York: Raven Press, 1985:1773-803.
16 Martha PM, Rogol AD, Veldhuis JD, Kerrigan JR, Goodman DW, Blizzard RM. Alterations in the pulsatile properties of circulating growth hormone concentrations during puberty in boys. F Clin Endocrinol Metab 1989;69: $563-70$.

17 Edge JA, Hourd P, Edwards R, Dungar DB. Urinary growth hormone during puberty in normal and diabetic children. Clin Endocrinol (Oxf) 1989;30:413-20.

18 Sukegawa I, Hizuka N, Takano $\mathrm{K}$, et al. Urinary growth hormone $(\mathrm{GH})$ measurements are useful for evaluating endogenous GH secretion. $\mathcal{f}$ Clin Endocrinol Metab 1988; 66:1119-23.

19 Albini $\mathrm{CH}$, Quattrin T, Vandlen I, Macgillivray $\mathrm{MH}$ Quantification of urinary growth hormone in children with Quantifcation of urinary growth hormone in children with

20 Okuna A, Yano K, Itoh Y, et al. Urine growth hormone determinations compared with other methods in the assessment of growth hormone secretion. Acta Paediatr Scand 987;337(suppl):74-81

21 Weissberger AJ, Ho KY, Stuart MC. Quantification of urinary growth hormone $(\mathrm{GH})$ excretion by centrifugal ultrafiltration and radioimmunoassay: appraisal of the relationship between $24 \mathrm{~h}$ urinary GH and mean $24 \mathrm{~h}$ serum GH levels in normal and abnormal states of GH secretion. Clin Endocrinol (Oxf) 1989;30:687-98.

22 Lunt $\mathrm{H}$, Tucker AJ, Bullen $\mathrm{H}$, Gibbs $\mathrm{C}$, Wilkin TJ. Overnight urinary growth hormone measurement in the diagnosis of acromegaly. Clin Endocrinol (Oxf) 1990;33. 205-12.

23 Hirschberg R, Kopple JD. Effects of growth hormone and IGF-1 on renal function. Kidney Int 1989;36(suppl 27): S20-6.

24 Skinner AM, Price DA, Addison GM, Herbert ED, Ashton AJ. Sources of variability in overnight urinary excretion of growth hormone, $\mathrm{N}$-acetylglycosaminidase, albumin, and creatinine in normal children. Horm Res 1990;33(supp 3):80

25 Hattori N, Kato Y, Murakami Y, et al. Urinary growth hormone levels measured by ultrasensitive enzym mmunoassay in patients with renal insufficiency. $7 \mathrm{Clin}$ Endocrinol Metab 1988;66:727-32.

26 Hattori N, Shimatsu A, Kato Y, et al. Urinary excretion of human growth hormone: daily variation and relationship with albumin and $\alpha$ microglobulin in urine. Acta Endocrinol (Copenh) 1989;121:533-7. 